\title{
ФОРМЫ ВЗАИМОДЕЙСТВИЯ КОНСТИТУЦИОННОГО СУДА РФ С КОНСТИТУЦИОННЫМИ (УСТАВНЫМИ) СУДАМИ СУБЪЕКТОВ РФ
}

Аннотация: Рассматривается статус Конституционного Суда РФ конституционных (уставных) судов субъектов РФ в ракурсе их взаимодействия между собой. Доказывается, что органы конституционной юстиции России не представляют собой иерархическую систему, но имеют возможность взаимодействовать между собой. Несмотря на то, что все условия для развития региональной конституционной юстиции со стороны Федерации созданы, они действуют только в 18 субъектах РФ из 83. Раскрываются формы такого взаимодействия: обеспечение конституционной законности, определение пределов полномочий и защита прав граждан. В работе были использованы диалектический, логчческий, формально-юридический, сравнительно-правовой методы, которые позволили изучить проблему взаимодействия органов конституционной юстиции России полно и всесторонне. Взаимодействие органов конституционной юстиции при обеспечении конституционной законности обусловливается единством подходов в толковании концептуальных положений действующих конституций и уставов субъектов РФ, где главная роль принадлежит Конституционному Суду РФ. Именно он дает официальное разъяснение о пределах компетенции органов конституционной юстиции субъектов Федерации. При взаимодействии в срере защиты прав граждан следует учитывать, что подходы конституционных (уставных) судов субъектов РФ и Конституционного Суда РФ к рассмотрению вопросов по защите прав граждан могут быть различны, тем более что в ряде субъектов РФ закрепляются дополнительные, по сравнению с другими полномочия органов конституционной юстиции по рассмотрению нормативных актов, нарушающих права граждан данного субъекта РФ. Делается вывод о том, что существование различных органов конституционного контроля в Российской Федерации, их эфрективное взаимодействие будет способствовать укреплению конституционной законности, защите прав граждан.

Ключевые слова: Конституционный Суд РФ, конституционные уставные суды, субъекты Российской Федерации, органы конституционного контроля, защита прав граждан, конституционная юстиция, формы взаимодействия, конституционная законность, пределы компетенции судов, полномочия конституционных судов.

DOI: 10.7256/1994-1471.2014.6.11385

K онституционный контроль в правовом государстве выступает существенной гарантией обеспечения конституционной законности. Осуществление конституционного контроля поручается различным органам, но наиболее качественно и квалифицированно его могут проводить специализированные органы, которыми чаще всего являются суды.

В России судебные органы конституционного контроля представлены на двух уровнях федеральном - Конституционный Суд РФ, и региональном - конституционные (уставные) суды субъектов РФ. Причем более чем двадцатилетнее совместное функционирование этих судебных органов вызывает необходимость ос- мыслить опыт их взаимодействия, его формы, выявить проблемы, которые препятствуют повышению эффективности их деятельности по защите конституционной законности.

В соответствии с частью 1 статьи 27 Федерального конституционного закона от 31.12.1996 № 1-ФКЗ (ред. от 25.12.2012) «0 судебной системе Российской Федерации»: «Конституционный (уставный) суд субъекта Российской Федерации может создаваться субъектом Российской Федерации для рассмотрения вопросов соответствия законов субъекта Российской Федерации, нормативных правовых актов органов государственной власти субъекта Российской Федерации,

(c) Лобанов Иван Васильевич

Кандидат юридических наук, доцент кафедры конституционного и международного права,

Российский экономический университет им. Г.В. Плеханова

[F-1248@mail.ru]

117997, Россия, г. Москва, ул. Зацепа, д. 41. 
органов местного самоуправления субъекта Российской Федерации конституции (уставу) субъекта Российской Федерации, а также для толкования конституции (устава) субъекта Российской Федерации»ํ. Поскольку создание таких судов - это право, а не обязанность субъекта Российской Федерации, в настоящее время они действуют только в 18 субъектах РФ из 83: в 14 республиках (Кабардино-Балкарской Республике, Республиках Адыгея, Башкортостан, Бурятия, Дагестан, Карелия, Коми, Саха (Якутия, Марий Эл, Северная Осетия - Алания, Татарстан, Тыва, Чечня, Ингушетия), 3 областях (Калининградской, Челябинской и Свердловской) и одном городе федерального значения (Санкт-Петербург).

Несмотря на то, что подавляющее большинство ученых-юристов выступают за создание таких судов во всех без исключения российских регионах, политическая практика идет по другому пути: большинство из конституционных (уставных) судов субъектов РФ были образованы около 20 лет назад, а в последние годы только несколько субъектов Федерации посчитали нужным создать у них данные судебные органы. Причем первым таким органом был Комитет конституционного надзора Республики Татарстан, который был образован 15 декабря 1990 года, а затем в 1992 году после принятия Конституции Республики Татарстан и Закона «О Конституционном Суде РФ» получил новое название. Последним был образован Уставной суд Челябинской области - в декабpe 2011 года. Основной причиной медлительности в создании органов конституционного контроля в субъектах РФ является то, что представители региональной политической элиты не видят необходимости на средства субъекта Федерации создавать еще один контролирующий орган, решения которого могут повлиять, в том числе, и на расстановку политических сил в регионе. Федеральные органы государственной власти не пытаются форсировать этот процесс, как это, например, сделано по отношению к институту Уполномоченного по правам человека, который действует в 79 субъектах РФ из имеющихся 83: в 20 республиках из 21 , 9 краях из 9, 44 областях, из 46, 3 автономных округах из 4 , автономной области и городах федерального значения Москва и Санкт-Петербург. Справедливости ради необходимо отметить, что и назначение данных региональных органов разное: если конституционные (уставные) суды призваны выявлять противоречия

СЗ РФ. 1997. № 1. Ст. 1; 2001. № 51. Ст. 4825; 2003. № 27. Ст. 2698; 2005. № 15. Ст. 1274; 2011. № 50. Ст. 7334; 2012. № 24. Ст. 3064; № 53 (ч. 1). Ст. 7572. 2014. №6. Ст. 549. с Основным законом, то уполномоченные по правам человека - мирным путем разрешать конфликты между гражданами и исполнительной властью.

Тем не менее все условия для развития региональной конституционной юстиции со стороны Федерации созданы. Так, по справедливому мнению Г.А. Жилина: «Федеральные правовые нормы ясно, четко и недвусмысленно ориентируют субъекты федерации (при условии соблюдения принципа единства государственной власти в РФ) на реализацию ими конституционных полномочий по самостоятельному достраиванию системы собственных органов государственной власти на основе ее разделения на законодательную, исполнительную и судебную посредством учреждения конституционного (уставного) суда. Следовательно, проблема отсутствия конституционного (уставного) суда в конкретном регионе относится в большей степени к сфере государственной правовой политики данного региона» ${ }^{2}$. Возможно, нежелание создавать специализированные органы конституционного контроля также обусловлено ложным представлением у лиц, принимающих решения на региональном уровне, о невостребованности их деятельности, небольшой загруженности. Однако это неверно, поскольку необходимость функционирования органов конституционной юстиции в субъектах Федерации очевидна, особенно в сфере защиты прав граждан. Только Уставным судом Свердловской области за 13 лет его работы вынесено 162 решения, признаны не соответствующими Уставу 50 нормативных актов, дано четыре толкования Устава. При этом следует обратить внимание на динамику роста обращений граждан. Так, в 2010 г. по сравнению с 2009 г. в отношении обращений граждан, по которым были вынесены итоговые решения, рост составил $128 \%$. А в 2011 г. в сравнении с аналогичным периодом 2010 г. - $166 \%{ }^{3}$. Приведенные статистические данные свидетельствуют еще об одной проблеме, о которой также говорят специалисты - нарушение принципа равенства прав и свобод человека в зависимости от его места жительства, обусловленное наличием или отсутствием в данном субъекте Федерации органов конституционной юстиции.

\footnotetext{
Жилин Г.А. Конституционное судопроизводство в субъектах РФ: основные проблемы // Российский юридический журнал. 2013. № 4. С. 48.

Пантелеев В.Ю. Актуальные вопросы модернизации и повышения эффективности работы конституционного правосудия в субъектах Российской Федерации // Конституционное и муниципальное право. 2012. № 3. C. $46-51$.
} 
Тем не менее недостаточное количество конституционных (уставных) судов субъектов РФ не может свидетельствовать об отсутствии актуальности вопросов, связанных с их взаимодействием с высшим федеральным органом конституционного контроля нашей страны. При этом необходимо понимать, что органы конституционного контроля в России не находятся в вертикальном подчинении, а решения региональных органов конституционной юстиции не могут быть отменены или пересмотрены федеральным судом. По мнению Т.Г. Морщаковой: «Конституционные (уставные) суды субъектов составляют с Конституционным Судом РФ не иерархическую систему, а систему институтов, объединенных общим конституционным пространством и едиными конституционными ценностями. Каждый из судов руководствуется разными конституционными критериями, соответственно, решения Конституционного Суда, основанные на Конституции РФ, обладают большей юридической силой, и выводы региональных конституционных (уставных) судов должны быть согласованы с ними» 4 .

Несмотря на то, что конституционная юстиция не представляет собой единую систему органов, взаимодействие внутри данной системы весьма значимо для института конституционного контроля, поскольку позволяет соизмерять действия и решения данных органов с их ролью в реализации конституционного правопорядка в нашей стране. Формы взаимодействия Конституционного Суда РФ и конституционных (уставных) судов субъектов РФ разнообразны. Среди них можно выделить следующие:

Bo-nервых, совместное обеспечение единства конституционно-правового пространства страны. Ведь целью создания данных судебных органов является приведение в соответствие с нормами федерального и региональных основных законов всех остальных положений законов и других нормативных актов. Эти суды, по мнения ряда ученых, осуществляют конституционное правосудие с целью обеспечения единой конституционной законности, действуют как партнеры в решении общих задач - обеспечения верховенства Конституции $\Phi^{5}$.

Такая деятельность способствует формированию единого подхода к законности, установлению единых правил для законодателей

\footnotetext{
4 Вестник Конституционного Суда РФ. 1998. № 4. C. 72-73.

Гатауллин А.Г. Теория и практика конституционного контроля в субъектах Российской Федерации: автореф. дисс. ... канд. юрид. наук, Казань, 2000. С. 10-11; Шахрай С.М. Конституционное правосудие в системе российского федерализма. СПб., 2001. С. 172.
}

и правоприменителей в целях обеспечения единства действия конституционных норм. Однако нельзя забывать о тех различиях, которые существуют в сфере конституционного контроля Российского федеративного государства. В этой связи справедливым является мнение С.Э. Несмеяновой: «Безусловно, органы конституционного контроля связаны между собой функционально как институты, обеспечивающие конституционную законность в Российской Федерации, тем не менее они не составляют единую, иерархическую систему, руководствуются в своей деятельности разными конституционными критериями» ${ }^{6}$.

Взаимодействие органов конституционной юстиции должно быть обусловлено единством подходов в толковании тех или иных концептуальных положений действующих конституций и уставов субъектов РФ, где главная роль принадлежит Конституционному Суду РФ. Как справедливо отмечает В.Ю. Пантелеев: «Несмотря на то, что органы региональной конституционной юстиции обладают своей компетенцией, они ориентируются на Конституционный Суд Российской Федерации, в том числе зачастую обосновывают свои решения правовыми позициями, выраженными в постановлениях Конституционного Суда Российской Федерации» ${ }^{7}$.

Во-вторых, важная форма взаимодействия состоит в том, что именно Конституционный Суд РФ дает официальное разъяснение о пределах компетенции органов конституционной юстиции субъектов Федерации. Ведь в федеральном законодательстве нет четкого перечня полномочий конституционных (уставных) судов субъектов Федерации, что позволяет региональным законодательным органам его дополнять и расширять. Как верно отмечает И.В Зыкова: «До настоящего момента на законодательном уровне не решен вопрос взаимодействия органов конституционного контроля субъектов Российской Федерации с иными органами судебной власти. Данный правовой пробел был «порожден» в результате наличия другого неурегулированного вопроса - определения полномочий данных судов, круга их компетенции» ${ }^{8}$ В данном случае взаимодейст-

6 Несмеянова С.Э. Конституционное судопроизводство: возможна ли инстанционность // Российский юридический журнал. 2013. № 4. С. 71.

Пантелеев В.Ю. Актуальные вопросы модернизации и повышения эффективности работы конституционного правосудия в субъектах Российской Федерации // Конституционное и муниципальное право. 2012. № 3. C. 46 .

8 Зыкова И.В. Статус конституционных (уставных) судов субъектов Российской Федерации // Конституционное и муниципальное право. 2013. № 2. С. 59. 
вие конституционных (уставных) судов с высшими судебными органами России выразилось в том, что именно они помогли субъектам РФ разобраться с перечнем полномочий данных судебных органов, четко устанавливая при этом, что не может быть и речи об отдельной судебной системе субъекта РФ

Отмечая, что конституционным (уставным) судам субъектов Российской Федерации неподведомственны дела, отнесенные Конституцией Российской Федерации, федеральными конституционными и федеральными законами к компетенции Конституционного Суда Российской Федерации, судов общей юрисдикции и арбитражных судов, Конституционный Суд Российской Федерации в определении от 6 марта 2003 г. указал, что вне этих пределов предоставление полномочий конституционным (уставным) судам субъектов Российской Федерации «не противоречит Конституции Российской Федерации, если эти полномочия соответствуют юридической природе и предназначению данных судов в качестве судебных органов конституционного (уставного) контроля и касаются вопросов, относящихся к ведению субъектов Российской Федерации в силу статьи 73 Конституции Российской Федерации. При этом из Конституции Российской Федерации и Федерального конституционного закона «0 судебной системе Российской Федерации», других федеральных законов не вытекает требование установления конституциями (уставами) субъектов Российской Федерации единообразного перечня полномочий конституционных (уставных) судов субъектов Российской Федерации» ${ }^{9}$. Таким образом, помимо указанных в федеральных законах полномочий органов конституционной юстиции субъектов РФ, субъект Федерации в пределах своих исключительных полномочий вправе наделять их своим законом другими полномочиями. Это подтвердил и Верховный Суд РФ в своем определении от 21 июля 2004 года: «Субъект Российской Федерации вправе вводить дополнительные, по сравнению с указанным в ч. 1 ст. 27 Федерального конституционного закона «0 судебной системе Российской Федерации» перечнем, полномочия конституционного (уставного) суда, не вторгающиеся в компетенцию Конституционного Суда Российской Федерации, других федеральных судов и

Определение Конституционного Суда РФ от 06.03.2003 № 103-О «По запросам Государственного Собрания Республики Башкортостан и Государственного Совета Республики Татарстан о проверке конституционности части 1 статьи 27 Федерального конституционного закона «О судебной системе Российской Федерации»// Вестник Конституционного Суда РФ. 2003. № 4. соответствующие компетенции субъекта Российской Федерации» ${ }^{10}$.

При отсутствии федерального закона об основах организации и деятельности конституционных (уставных) судов субъектов Российской Федерации, о необходимости разработки которого многократно писали ученые-конституционалисты, влияние Конституционного Суда РФ на определение статуса и полномочий данных судебных органов весьма значительно. По обоснованному мнению А.А. Петрова: «Конституционный Суд внес в развитие регионального конституционного (уставного) правосудия явно более весомый вклад, нежели федеральный законодатель» ${ }^{11}$.

$B$-третьих, одной из важнейших форм взаимодействия федерального и региональных органов конституционного контроля выступает защита прав граждан. Учитывая то, что в соответствии с пунктом «б» ст.72 Конституции РФ защита прав и свобод человека и гражданина относится к предметам совместного ведения России и её субъектов, объединенная деятельность в данной сфере органов публичной власти различного уровня представляется необходимой. Особую значимость этот вид деятельности имеет для органов конституционной юстиции. Как пишет Г.А. Жилин: «Эта цель является обязательной и приоритетной для всех органов конституционной судебной юрисдикции вне зависимости от последовательности формулирования в законодательстве целей конституционного судопроизводства и наличия при их перечислении в законе прямого указания на защиту основных прав и свобод человека и гражданина» ${ }^{12}$.

Однако, нисколько не умаляя важности и значимости данной формы взаимодействия органов конституционной юстиции России, необходимо учитывать, что подходы конституционных (уставных) судов субъектов РФ и Конституционного Суда РФ к рассмотрению вопросов по защите прав граждан могут быть различны, тем более, что в ряде субъектов РФ закрепляются дополнительные, по сравнению с другими, полномочия органов конституционной юстиции по рассмотрению нормативных актов, нарушающих права граждан данного субъекта РФ.

10 Определение Президиума Верховного Суда РФ от 21.07.2004 // Бюллетень Верховного Суда РФ. 2005. № 2.

Петров А.А. Правовые позиции Конституционного Суда Российской Федерации по вопросам организации и деятельности конституционных (уставных) судов субъектов Российской Федерации // Журнал конституционного правосудия. 2013. № 3. С. 32.

12 Жилин Г.А. Единство конституционного судопроизводства в Российской Федерации // Журнал конституционного правосудия. 2012. № 1. С. 3. 
Например, в Законе о Конституционном суде Республики Коми сказано, что этот суд «по жалобам на нарушение конституционных прав и свобод граждан и по запросам судов проверяет конституционность нормативного правового акта, примененного или подлежащего применению в конкретном деле, по вопросам, относящимся к ведению органов государственной власти Республики Коми и органов государственной власти РФ, а также по вопросам, относящимся к ведению представительных и исполнительных органов местного самоуправления» ${ }^{13}$.

Именно поэтому Законодательное собрание Санкт-Петербурга в декабре 2011 года обратилось в Государственную Думу Федерального Собрания РФ с законодательной инициативой «О внесении изменений в Федеральный конституционный закон «О Конституционном Суде Российской Федерации» и статью 27 Федерального конституционного закона «0 судебной системе Российской Федерации» ${ }^{14}$. В проекте предлагалось закрепить новое полномочие Конституционного Суда РФ - проверять на соответствие Конституции РФ выявленный конституционным (уставным) судом субъекта смысл положений конституции (устава) субъекта, закона субъекта, иного нормативного правового акта, который был предметом рассмотрения в региональном органе конституционного судебного контроля. Этот законопроект вызвал бурную дискуссию среди специалистов. Одни из них предлагают поддержать данный законопроект, другие категорически с ним не согласны. Так, О. А. Кожевников считает, что «на первом этапе предлагаемые нововведения существенным образом увеличат количество обращений заявителей, недовольных решениями конституционной (уставной) юстиции субъектов РФ, но постепенно, с выработкой практики Конституционным Судом РФ в этой сфере судопроизводства, полагаем, что таких обращений будет гораздо меньше, а уровень обеспечения соответствия Конституции РФ судебной практики конституционных (уставных) судов субъектов РФ существенным образом вырастет» ${ }^{15}$.

\section{Библиография:}

1. Гатауллин А.Г. Теория и практика конституционного контроля в субъектах Российской Федерации: автореф. дисс. ... канд. юрид. наук. Казань, 2000. - 25 с.

2. Зыкова И.В. Статус конституционных (уставных) судов субъектов Российской Федерации // Конституционное и муниципальное право. 2013. № 2. - С. 56-59.

\footnotetext{
13 СПС КонсультантПлюс.

14 СПС КонсультантПлюс.

15 Кожевников О.А. Подведомственность споров конституционным (уставным) судам субъектов РФ: проблемы правоприменения // Конституционное и муниципальное право. 2012. № 7. С. 43.
}

Мы согласны с противоположным мнением, высказанным С.Э. Несмеяновой, которая считает, что «в данном случае: Конституционный Суд РФ при рассмотрении подобных дел будет вынужден проверять оспариваемый в региональном суде нормативный акт, а также соответствующие положения конституции (устава) субъекта (на основе которых было принято решение в субъекте). Таким образом, Конституционный Суд фактически будет рассматривать дело по существу в отношении актов, не предусмотренных ни Конституцией РФ, ни ФКЗ о Конституционном Суде РФ» ${ }^{16}$. А потому взаимодействие в сфере защиты прав человека органов конституционной юстиции России может заключаться только в выработке единой позиции по вопросам защиты прав граждан, оказании консультационной и методической помощи, а не отмене или пересмотре решения конституционного (уставного) суда субъекта РФ Конституционным Судом РФ. Данное положение закреплено в § 76 Регламента Конституционного Суда РФ: «Конституционный Суд взаимодействует с иными судами и с органами конституционного (уставного) контроля субъектов Российской Федерации в целях взаимного изучения опыта, осуществления информационного обмена, а с органами конституционного (уставного) контроля субъектов Российской Федерации - также в целях оказания им методической помощи» ${ }^{17}$.

Таким образом, взаимодействие между Конституционным Судом РФ и конституционными (уставными) судами субъектов РФ реализуется в нескольких формах: обеспечения верховенства Конституции Российской Федерации на всей территории России и конституций (уставов) субъектов РФ на территории данных субъектов Федерации, единства конституционного строя на всей территории страны, установление пределов полномочий каждого из видов органов конституционного контроля, а также обязательность совместной деятельности по защите конституционных прав российских граждан.
16 Несмеянова С.Э. Конституционное судопроизводство: возможна ли инстанционность // Российский юридический журнал. 2013. № 4. С. 67.

Регламент Конституционного Суда РФ (ред. от 24.01.2011) // СПС КонсультантПлюс. 
3. Жилин Г.А. Единство конституционного судопроизводства в Российской Федерации // Журнал конституционного правосудия. 2012. № 1. - С. 1-7.

4. Жилин Г.А. Конституционное судопроизводство в субъектах РФ: основные проблемы // Российский юридический журнал. 2013. № 4. - С. 48-53.

5. Кожевников О.А. Подведомственность споров конституционным (уставным) судам субъектов РФ: проблемы правоприменения // Конституционное и муниципальное право. 2012. № 7. - С. 39-43.

6. Несмеянова С.Э. Конституционное судопроизводство: возможна ли инстанционность // Российский юридический журнал. 2013. № 4. - С. 66-71.

7. Пантелеев В.Ю. Актуальные вопросы модернизации и повышения эффективности работы конституционного правосудия в субъектах Российской Федерации // Конституционное и муниципальное право. 2012. № 3. - С. 46-51.

8. Петров А.А. Правовые позиции Конституционного Суда Российской Федерации по вопросам организации и деятельности конституционных (уставных) судов субъектов Российской Федерации // Журнал конституционного правосудия. 2013. № 3. - С. 25-32.

9. Шахрай С.М. Конституционное правосудие в системе российского федерализма. СПб., 2001. $172 \mathrm{c.}$

10. Шахрай С.М. Роль решений Конституционного Суда Российской Федерации в становлении конституционной модели российского федерализма // Журнал зарубежного законодательства и сравнительного правоведения. - 2012. - 2. - С. 27-36.

11. Балабкин С. И. Об окончательности решений Конституционного Суда Российской Федерации // Право и политика. - 2012. № 4. - С. 689-695.

12. Кожевников О. А. Некоторые проблемы в разграничении подведомственности споров между судами общей юрисдикции и конституционными (уставными) судами субъектов РФ и пути их разрешения // Право и политика. - 2012. № 5. - С. 897-901.

\section{References:}

1. Gataullin A.G. Teoriya i praktika konstitutsionnogo kontrolya v sub"ektakh Rossiiskoi Federatsii: avtoref. diss. ... kand. yurid. nauk. Kazan', 2000. - 25 s.

2. Zykova I.V. Status konstitutsionnykh (ustavnykh) sudov sub"ektov Rossiiskoi Federatsii // Konstitutsionnoe i munitsipal'noe pravo. 2013. № 2. - S. 56-59.

3. Zhilin G.A. Edinstvo konstitutsionnogo sudoproizvodstva v Rossiiskoi Federatsii // Zhurnal konstitutsionnogo pravosudiya. 2012. № 1. - S. 1-7.

4. Zhilin G.A. Konstitutsionnoe sudoproizvodstvo v sub"ektakh RF: osnovnye problemy // Rossiiskii yuridicheskii zhurnal. 2013. № 4. - S. S. 48-53.

5. Kozhevnikov O.A. Podvedomstvennost' sporov konstitutsionnym (ustavnym) sudam sub"ektov RF: problemy pravoprimeneniya // Konstitutsionnoe i munitsipal'noe pravo. 2012. № 7. - S. 39-43.

6. Nesmeyanova S.E. Konstitutsionnoe sudoproizvodstvo: vozmozhna li instantsionnost' // Rossiiskii yuridicheskii zhurnal. 2013. № 4. - S. 66-71.

7. Panteleev V.Yu. Aktual'nye voprosy modernizatsii i povysheniya effektivnosti raboty konstitutsionnogo pravosudiya v sub"ektakh Rossiiskoi Federatsii // Konstitutsionnoe i munitsipal'noe pravo. 2012. № 3. - S. 46-51.

8. Petrov A.A. Pravovye pozitsii Konstitutsionnogo Suda Rossiiskoi Federatsii po voprosam organizatsii i deyatel'nosti konstitutsionnykh (ustavnykh) sudov sub"ektov Rossiiskoi Federatsii // Zhurnal konstitutsionnogo pravosudiya. 2013. № 3. - S. 25-32.

9. Shakhrai S.M. Konstitutsionnoe pravosudie v sisteme rossiiskogo federalizma. SPb., 2001. - $172 \mathrm{~s}$.

10. Shakhrai S.M. Rol' reshenii Konstitutsionnogo Suda Rossiiskoi Federatsii v stanovlenii konstitutsionnoi modeli rossiiskogo federalizma // Zhurnal zarubezhnogo zakonodatel'stva i sravnitel'nogo pravovedeniya. - 2012. - 2. - C. 27-36.

11. Balabkin S. I. Ob okonchatel'nosti reshenii Konstitutsionnogo suda Rossiiskoi Federatsii // Pravo i politika. - 2012. - 4. - C. 689-695.

12. Kozhevnikov 0. A. Nekotorye problemy v razgranichenii podvedomstvennosti sporov mezhdu sudami obshchei yurisdiktsii i konstitutsionnymi (ustavnymi) sudami sub"ektov RF i puti ikh razresheniya // Pravo i politika. - 2012. - 5. - C. 897-901. 